\title{
THE IMPLEMENTATION OF DEBATE TECHNIQUE TO IMPROVE STUDENTS' ABILITY IN SPEAKING
}

\author{
Farisha Andi Baso
}

\author{
English Education Department, Faculty of Teacher Training and Education \\ Muhammadiyah University of Makassar \\ farisha@unismuh.ac.id
}

\begin{abstract}
This study aimed at finding out the students' speaking skill by using debate.The research design used a pre-experimental, in which it used pre-test and post-test comparison to find out the result of the research. The population of the research was all students of the Eleventh Grade Students of SMA Perguruan Tinggi Islam Makassar which consisted of three classes. Each class consists of more than 20 students, so the total number of population was 85 students. Among the total number of population, the researcher took one class to be sample of this research by using purposive sampling technique. The instruments of this research were speaking test and recording. To analyze the score of the students' achievement in pre-test and post-test, the researcher used t-test analyzes. The result of the data showed that there was a significant difference between pre-test and post-test. The value of t-test (6.35) was greater than the t-table (1.729) at the level of significant $(p)=0.05$ and degree of freedom $(d f)=19$. It can be said that the null hypothesis $\left(H_{0}\right)$ was rejected and the alternative hypothesis $\left(H_{1}\right)$ was accepted. Which means that there was a significant difference between the students' speaking ability before and after using debate or it can be said that the use of debate was effective in improving the students' speaking skill at the Eleventh Grade of SMA Perguruan Tinggi Islam Makassar?
\end{abstract}

Keywords: Debate Technique, Speaking Ability

\section{INTRODUCTION}

The use of English as an international language plays a significant role in globalization era. At the present time, we are required to be able to communicate in English. Meanwhile, Indonesian education approves the use of Indonesian language as the national language. The evidence of its importance is to put English as one of the subjects to be tested in the national examination (UN). English is not a second language in Indonesia, it is considered to be a foreign language. English is taught from Elementary to University level. The objective of teaching and learning English at schools is to bring up student to better understanding and ability of the language. Students, however, are required to achieve certain score in order to pass. Not only grammatical aspect is important but also is communicative ones. As it is stated in the English curriculum that 
students' material must be based on communicative ability acceptable for students' daily needs. It sums up that all language ability of English must be integrative put up together so that good English mastery is laid in.

In teaching English, there are four micro abilities: listening, Reading, Writing, and Speaking. The following discussion in this research is mainly focus on speaking. According to Hornby (1995: 318), speaking is making use of word in an ordinary voice, uttering words, knowing and being able to use a language; expressing one in words; making a speech. In short, speaking ability is the ability to perform the linguistics knowledge in the actual communication. By speaking with other, we are able to know what kinds of situation are in the world. "Speaking is an interactive process of constructing meaning that involves producing and receiving and processing information" (Brown\& Yule, 1994; Burns \& Joyce, 1997).Speaking is like the first assessment for each learner who is studying English and each learner has to speak. This statement means an obligation, duty, task, fact, implementation, process, and it can be learning, although we still find some students are speaking little or even passive in the classroom, and it can be caused of many things include the students, the class situation, environment, teaching method, technique, approach or even from the teachers who cannot deliver their material successfully.

The achievement of good speaking activity is when people who interact can understand each other. One obvious example of speaking activity is any interaction between teacher and student. In the interaction, the teacher should have a good speaking competence because he has to bring all of his students to understand the material through his speech.

Besides that, the other problem came from the teacher; he/she still used monotonous activity in teaching and learning process. The teacher always used imitation and repetition technique all the time. According to Thirumalai (2002), imitation includes the capacity to produce the utterances in the contexts in which the original utterances were produced. This activity made the teaching and learning process is not interesting to the students.

Concerning to techniques in teaching speaking, the English teacher have to be aware of innovative ways and well selected techniques in teaching especially in 
teaching speaking ability. According to Dobson (1987), there are some techniques in improving speaking, one of them is debate technique.Debate improves speaking ability, whether scientific, historical, religious or political. It can contributes to the intellectual and ethical development of its participant by challenging them to make defensible judgment in which they must critically investigate complex Issue, question given assumptions debate stimulates and refines communication ability that empower individuals to speak from themselves.

Based on the researcher's informal interview with the teacher in SMA Perguruan Islam Makassar, This school is chosen because the researcher found that most students are difficult to engage in speaking activity, beside that they said vocalized pause, lost idea, and they were sometime obviously afraid of making mistake, few students who spoke English and they also tend to use inappropriate grammar. Therefore, it is important to conduct the research on this topic.

\section{THE CONCEPT OF SPEAKING}

Speaking is a very important part of second language learning. The ability to communicate in a second language clearly and efficiently contributes to the success of the learner in school and success later in every phase of life. Inside the classroom, speaking and listening are the most often used ability s (Brown, 1994). They are recognized as critical for functioning in an English language context, both by teachers and by learners. These ability s are also logical instructional starting points when learners have low literacy levels (in English or their native language) or limited formal education, or when they come from language backgrounds with a non-Roman script or a predominantly oral tradition.

There are many definition of speaking. Hornby (1990:1227) defines speaking is making use of words in an ordinary voice. Lawtie (2007), states that speaking is the fundamental to the human's communication. He adds that communication through speaking is performed face to face interaction and occurs as part of a dialogue or other form of verbal exchange. Harmer (1990:41) there are some purposes of someone doing communication: (1) He wants to speak, (2) $\mathrm{He}$ has some communicative purpose the selects from his language store, (3). He 
wants to listen to something and he is interested in the communicative purpose of what is being said.

In other hand, Mead and Rubin (1985) say that speaking is an interactive process in which an individual alternately takes the roles of speaker and listener, and which includes both verbal and nonverbal component. Chaney in Kanyi (2006) adds that Speaking is the process of building and sharing meaning through the use of verbal and non-verbal symbols, in a variety of contexts. It means speaking is interaction between speakers with a listener. O’Malley (1996:59) speaking means negotiating intended meanings and adjusting one's speech to produce the desired effect on the listener.

Finocchiaro (1983:32) explain that there are six important things to be considered in speaking ability. There are: (1) To decide what the learner want to say, (2) to select words that fall into pattern they are going to use, (3) to select words that fall into pattern conveying the meaning, (4) to use correct arrangement of word, (5) to make sure the appropriate situation, and (6) to place tongue and lips in certain position to produce sounds. Moreover, Chafe in Renkema (1993: 86) says speaker and listener are more involved in communication than writer and reader.

Based on the curriculum 2004 the students are intended to have the English ability in listening, speaking, reading, and writing. Meanwhile Widdowsoon defines that speaking is the physical embodiment of abstract system which involves the manifestations either of the phonologically system or of the grammatical system of the language or both. For example in "he speaks clearly" clarity or distinctiveness of speech refers to the manner in which the phonetic system of the language is manifested in "he speaks correctly" the meaning is what he says conforms to the accepted reveals for sentences formation. According to Mukminatien (1999: 4) Speaking ability is complicated because it covers various language components (Grammar, vocabulary, pronunciation, etc.) It refers not only to the grammatical system of the language but lexical system.

From the above definition, the researcher can conclude that speaking is particular ability that has many functions in daily life. By speaking we can share our ideas, feeling, and intentions that we are able to interact with ones others. 


\section{Component of Speaking}

According to Harris (1994: 81), there are five components of language that influence speaking ability. They are:

a. Pronunciation

Pronunciation is very important in speaking if we do not appropriate pronunciation it can influence meaning of word. Hornby (1995: 928) pronunciation is the way in which a language is spoken, the way in which a word is pronounced, the way a person speaks the words of language.

b. Grammar

Mastering grammar knowledge will help one in speaking English, because he will know how to arrange word in sentence, what tense will be used, how to use appropriate utterance. In other word, grammar is important role to master the spoken of the language.

c. Vocabulary

Mastering vocabulary is first step to speaking English if we do not master vocabulary, we can be not utterance what is our purpose.

d. Fluency

In speaking, we must speak fluency because listeners are able to response what we say.

e. Comprehension.

In speaking, comprehension is needed if not misunderstanding will happen between speaker and listener and the communication cannot run well.

\section{Types of Speaking}

There are two types of language: formal and informal. In general, someone use formal speaking in teaching learning process like the teacher with the students and someone who has higher status. Informal speaking, someone speaks with friends and family.

According to Kanyi, (2006: 76) say that in all language the forms people use when speaking formally are different from those used informal. In English, someone tends to use formal speech with stranger and people of higher status, and informal speech with family, friends and colleagues. And they add that formal and informal speech is differentiated in two basic ways: by style and by content, 
formal speech is characteristic by embedding and a tendency toward more complete sentences as opposed to fragment. Informal speech is characterized stylistically by omission, elisions, reductions and sometime, a faster speaking rate.

Based on explanation above, the researcher concludes that someone tend to use formal speech when interaction among the teacher with students in teaching learning process or to people of higher status. And someone use informal speech when they speak with their family, friends.

\section{THE CONCEPT OF DEBATE}

Debate is process of presenting idea or opinion which two opposing parties try to defend their idea or opinion. There some perception about debate technique, such as:

a. Krieger (2007) says that Debate is an excellent activity for language learning because it engages students in a variety of cognitive and linguistic ways.

b. Halvorsen (2005) says that debate forces students to think about the multiple sides of an issue and it also forces them to interact not just with the details of a given topic, but also with one another.

c. Maryadi in Khoironiyah (2011:26), states that debate can motivate students' thinking, more over if they must defend their stand or opinion which is contradiction with conviction themselves.

d. Debating is a structured contest of argumentation in which two opposing individuals or teams defend and attack a given proposition Debates require students to engage in research, encourage the development of listening and oratory ability s, create an environment where students must think critically, and provide a method for teachers to assess the quality of learning of the students. Debates also provide an opportunity for peer involvement in evaluation. (http://olc.spsd.sk.ca/De/PD/instr/strats/debates/index.html).

According to Thompson in Inoue (1996), debate is contrasted with discussion. The distinction in their use in referring to a decision-making process may be outlined as follows: 
a. In debate, participants argue for and against the pre-fixed proposition. In discussion, participants look for a solution to a problem.

b. Consequently, debate considers two alternatives, while discussion considers multiple alternatives.

c. Debate is usually regulated by strict rules about the time and order of speeches. Discussion is conducted more freely with less formal rules.

d. In debate, the decision is made by a third party based on the arguments presented by the affirmative and the negative sides. In discussion, the purpose is to reach an agreement among participants.

Moreover, according to Leo in Azma (2008) there are some objectives to be achieved through debate, there are: first, encourage students to practice speaking. Second, give students ample opportunities to speak English during their leisure time. Third, increase students' motivation to speak. Four, make them realize that learning English is not as difficult as they think. Five, practice English without thinking much about grammar. Six, let students realize that they can learn English from their parents, friend, classmate and other. Seven, make sure that everybody can learn English at their free time. Eight, develop students' courage to speak English. The last, make children be able to participate in everyday conversation with their interlocutor.

Based on the explanation above, the writer concluded that debate is competition of argument or ideas or opinion involving critical thinking process and speaking ability in which there are two opposing parties face to face and each other defend their ideas or opinion or argument by rational reason.

\section{Form of Debate}

There are many kinds of debate which used in the world. All forms of debate, whether consciously or not, make certain assumptions about argumentation theory. The core concept of argumentation theory is the notion of advocacy. In most cases, at least one side in a debate needs to maintain the truth of some proposition or advocate some sort of personal or political change or action. A debate could also potentially be between two or more competing propositions or actions. Or debate also could be a purely performative exercise of 
charisma and emotion with no assumption of fixed advocacy, but it would possibly lose much of its coherence.

Steven (2012:56) states that the kind of debate which familiar in the world can be explained bellow:

a. Parliamentary (Parli Debate)

Parliamentary Debate (sometimes referred to as "parli" in the United States) is conducted under rules derived from British parliamentary procedure. It features the competition of individuals in a multi-person setting. It borrows terms such as "government" and "opposition" from the British parliament (although the term "proposition" is sometimes used rather than "government" when debating in the United Kingdom).

b. Mace Debate

This style of debate is prominent in Britain at schools level. Two teams of two debate an affirmative motion (e.g. "This house would give prisoners the right to vote,") which one team will propose and the other will oppose. Each speaker will make a seven minute speech in the order; 1st Proposition, 1st Opposition, 2nd Proposition, 2nd Opposition. After the first minute of each speech, members of the opposing team may request a 'point of information' (POI). If the speaker accepts they are permitted to ask a question. POI's are used to pull the speaker up on a weak point, or to argue against something the speaker has said. However after 6 minutes, no more POI's are permitted. After all four have spoken the debate will be opened to the floor, in which members of the audience will put questions to the teams. After the floor debate, one speaker from each teams (traditionally the first speaker), will speak for 4 minutes. In these summary speeches it is typical for the speaker to answer the questions posed by the floor, answer any questions the opposition may have put forward, before summarizing his or her own key points. In the Mace format, emphasis is typically on ability, entertainment, style and strength of argument. The winning team will typically have excelled in all of these areas.

c. Public Debate 
The International Public Debate Association (IPDA) offers both team debates where two teams of two debate and individual debate. In both team and individual debate a list of topics are given to the two sides thirty minutes before the start of the round. A striking negotiation ensues to pick a topic. The sides, one affirming the resolution and one negating the resolution, then prepare an opening speech, a cross-examination of the other side, and closing remarks for the round.

d. Australasia Debate

Australasia style debates consist of two teams who debate over an issue, more commonly called a topic or proposition. The issue, by convention, is presented in the form of an affirmative statement beginning with "That", for example, "That cats are better than dogs," or "This House", for example, "This House would establish a world government." The subject of topics varies from region to region. Most topics however, are usually region specific to facilitate interest by both the participants and their audiences.

Each team has three members, each of whom is named according to their team and speaking position within his/her team. For instance the second speaker of the affirmative team to speak is called the "Second Affirmative Speaker" or "Second Proposition Speaker", depending on the terminology used. Each of the speakers' positions is based around a specific role; the third speaker for example has the opportunity to make a rebuttal towards the opposing teams' argument introducing new evidence to add to their position. The last speaker is called the "Team Advisor/Captain". Using this style, the debate is finished with a closing argument by each of the first speakers from each team and new evidence may not be introduced. Each of the six speakers (three affirmative and three negative) speak in succession to each other beginning with the Affirmative Team. The speaking order is as follows: First Affirmative, First Negative, Second Affirmative, Second Negative, Third Affirmative, and finally Third Negative.

e. Presidential Debate 
The presidential debates were initially moderated in 1976, 1980, 1984 by the League of Women Voters, but The Commission on Presidential Debates (CPD) was established in 1987 by the Republicans and Democrats to "ensure that debates, as a permanent part of every general election, provide the best possible information to viewers and listeners." Its primary purpose is to sponsor and produce debates for the United States presidential and vice presidential candidates and to undertake research and educational activities relating to the debates. The organization, which is a nonprofit, nonpartisan corporation, sponsored all the presidential debates in 1988, 1992, 1996, 2000 and 2004. However, in announcing its withdrawal from sponsoring the debates, the League of Women Voters stated that it was withdrawing "because the demands of the two campaign organizations would perpetrate a fraud on the American voter." In 2004, the Citizens' Debate Commission was formed in the hope of establishing an independent sponsor for presidential debates, with a more voter-centric role in the definition of the participants, format, and rules.

\section{The Basic of Debating Ability}

Inoun (1996:56) states that the kind of the basic of debating ability, namely:

a. Style

Style is the manner in which you communicate your arguments. This is the most basic part of debating to master. Content and strategy are worth little unless you deliver your material in a confident and persuasive way.

b. Speed

It is vital to talk at a pace which is fast enough to sound intelligent and allow you time to say what you want, but slow enough to be easily understood.

c. Tone

Varying tone is what makes you sound interesting. Listening to one tone for an entire presentation is boring.

d. Volume 
Speaking quite loudly is sometimes a necessity, but it is by no means necessary to shout through every debate regardless of context. There is absolutely no need to speak any more loudly than the volume at which everyone in the room can comfortably hear you. Shouting does not win debates. Speaking too quietly is clearly disastrous since no one will be able to hear you.

e. Clarify

The ability to concisely and clearly express complex issues is what debating is all about? The main reason people begin to sound unclear is usually because they lose the "stream of thought" which is keeping them going. It is also important to keep it simple. While long words may make you sound clever, they may also make you incomprehensible.

f. Use of notes and eye contact

Notes are essential, but they must be brief and well organized to be effective. There is absolutely no point in trying to speak without notes. Of course, notes should never become obtrusive and damage your contact with the audience, nor should they ever be read from verbatim. Most people sketch out the main headings of their speech, with brief notes under each.

When writing notes for rebuttal during the debate, it is usually better to use a separate sheet of paper so you can take down the details of what the other speakers have said and then transfer a rough outline onto the notes you will actually be using.

\section{The Principle of Good Debate}

Inoun (1996:70) states that the principle of good debate,those are:

a. Questions or challenges should be professional. Insulting, condescending, or comments involving personal language or attacks are unacceptable.

b. Critical analysis, synthesis, rhetorical ability, and wit are keys to debate success.

c. Focus on the opposing side's position or argument. Knowing the "other side" is critical for preparing strategies to refute your opponent's arguments. 
d. Limit your arguments to three or less.

e. Use logic to make your arguments. Present these arguments clearly and concisely.

f. Know the common errors in thinking like logical fallacies and use them effectively in your refutation.

g. Present the content accurately. Only use content that is pertinent to your point of view and draw on support from authoritative sources.

h. Be certain of the validity of all external evidence presented for your arguments. Also, challenges to the validity of evidence should be made only on substantive grounds.

i. Your rebuttal (or conclusion) in a debate is your final summary position. Use it as an opportunity to highlight important issues that indicate proof of your points or refute your opponent's argument.

\section{Debate Technique}

Inoun (1996:85) explains that Debating in the classroom can take many forms. Though not an all-inclusive list, the following debate methods offer a range of opportunities to increase student understanding and involvement with course material. This section will discuss the following types of debate: four corner, roleplay, fishbowl, think-pair-share, and meeting house.

The four corner debate starts with a question or statement, such as: "The federal health care law is a constitutional exercise of the commerce clause." Students are then afforded time to personally consider the statement and their view based on the law. The four corners of the classroom are labeled "strongly agree," "agree," “disagree," and "strongly disagree." After personal consideration, the students move to the corner that most represents their position on the issue. The groups in each corner of the classroom worked together to come up with the best arguments for their position. After a specified time for group discussion, each group presents their strongest arguments to the others group. This can be made in presentation form or through a more directed debate where the professor or assigned students can moderate and direct time for each group to present and rebut. After the debate, students are permitted to switch sides if their personal views changed. This form of debate directly counters the argument of dualism, 
showing there are more than two-sides to an issue, and often, variations of the sides.

\section{RESEARCH METHODOLOGY}

This research employed an Experimental Research Method that applies One-Group Pretest-Posttest Design. This design involved one group that applies pretest and posttest, where the pretest was administered before giving treatment by using Debate Technique and posttest was administered after giving treatment. The group received treatment by using Debate.

The population of this research was the Eleventh Grade of SMA Perguruan Tinggi Islam Makassar, in academic year 2013/2014. There were three classes and each class consisted of more than 20 students. The total numbers of population were 85 students. This research employed the technique namely using purposive sampling that was chosen one of the third classrooms of the population; it was class VII IPA ${ }_{1}$, and the numbers of samples were 20 students.

In conducting the data, the researcher used the speaking test and recording. Type of the test that was used in this research was Responsive Speaking, question and answer. Brown (2004: 159) states that "task can consist of one or two questions from an interviewer, or they can make up the portion of the whole battery of questions and prompts in an oral interview". Based on what was said by Brown above, in this case the researcher interviewed the students as the test-takers about an issue that they had been debated.

\section{FINDINGS AND DISCUSSION}

\section{A. Findings}

The findings of this research deal with the students' score. They are the students' score classification, the mean scores and standard deviation of pre-test and post-test, the t-test value, and hypothesis testing. These findings describe as follows: 


\section{The Students' Speaking Ability}

The students' score of pre-test and post-test are observed based components of speaking. The data can be seen in the following table:

Table 1.Frequency and Rate Percentage of the Students' Speaking Ability on accuracy

\begin{tabular}{|l|c|l|c|c|c|c|}
\hline \multirow{2}{*}{ No } & \multirow{2}{*}{ Score } & \multirow{2}{*}{ Category } & \multicolumn{2}{|c|}{ Pre-test } & \multicolumn{2}{c|}{ Post-test } \\
\cline { 4 - 7 } & & & Frequency & Percentage & Frequency & percentage \\
\hline 1 & $9.6-10$ & Excellent & - & 0 & - & 0 \\
\hline 2 & $8.6-9.5$ & Very good & - & 0 & - & 0 \\
\hline 3 & $7.6-8.5$ & Good & - & 0 & 3 & 15 \\
\hline 4 & $5.6-6.5$ & Fairly & 5 & 25 & 16 & 80 \\
\hline 5 & $3.6-5.5$ & Poor & 8 & 40 & 1 & 5 \\
\hline 5 & $0.0-3.5$ & Very Poor & 7 & 35 & - & 0 \\
\hline & TOTAL & & 20 & $100 \%$ & 20 & $100 \%$ \\
\hline
\end{tabular}

The table above shows that in the pre-test, there are 8 students or $40 \%$ categorized as poor, 5 students or $25 \%$ categorized as fairly, 7 students or $3.35 \%$ categorized as very poor, and none of them categorized as good, Very Good and excellent.

The table above also shows that the result of students' speaking ability in post-test accuracy. There is 1 student categorized as poor or $5 \%, 16$ students or $80 \%$ categorized as fairly, 3 students or $15 \%$ categorized as good and none of them classified into very good and excellent. 
Table 2.Frequency and Rate Percentage of the Students' ability in fluency

\begin{tabular}{|l|c|l|c|c|c|c|}
\hline \multirow{2}{*}{ No } & \multirow{2}{*}{ Score } & \multirow{2}{*}{ Category } & \multicolumn{2}{|c|}{ Pre-test } & \multicolumn{2}{c|}{ Post-test } \\
\cline { 4 - 7 } & & & Frequency & Percentage & Frequency & percentage \\
\hline 1 & $9.6-10$ & Excellent & - & 0 & - & 0 \\
\hline 2 & $8.6-9.5$ & Very good & - & 0 & - & 0 \\
\hline 3 & $7.6-8.5$ & Good & - & 0 & 10 & 50 \\
\hline 4 & $5.6-6.5$ & Fairly & 6 & 30 & 10 & 50 \\
\hline 5 & $3.6-5.5$ & Poor & 8 & 40 & - & 0 \\
\hline 5 & $0.0-3.5$ & Very Poor & 6 & 30 & - & 0 \\
\hline & TOTAL & & 20 & $100 \%$ & 20 & $100 \%$ \\
\hline
\end{tabular}

The table above shows that in the pre-test, there are 8 students or $40 \%$ categorized as poor, 6 students or $30 \%$ classified into very poor score, 6 students or $30 \%$ classified into fairly score, and none of them classified into Very Good, good and excellent score.

The table above also shows that the result of students' speaking ability in fluency in post-test. There is no student categorized as poor, very poor, very good, and excellent, 10 students or $50 \%$ categorized as fairly, 10 students or $50 \%$ categorized as good.

\section{Hypothesis testing}

To know the level of significance of the pre-test and post-test, the researcher uses t-test analysis on the level of significance $(\mathrm{p})=0.05$ with the degree of freedom $(\mathrm{df})=\mathrm{N}-1 \quad(20-1=19)$, where $\mathrm{N}=$ number of subject $(20$ students) then the value of t-table is 1.729 . The t-test statistical, analysis for independent sample is applied. The following table shows the result of t-test calculation: 
Table 4.3.The t-test of the Students' Improvement

\begin{tabular}{|l|c|c|}
\hline \multicolumn{1}{|c|}{ Components } & t-test value & t-table value \\
\hline accuracy & 5.39 & 1.729 \\
\hline fluency & 7.35 & 1.729 \\
\hline Speaking ability & 6.35 & 1.729 \\
\hline
\end{tabular}

The table above 4.3 shows that t-test value for accuracy is greater than $t$ table (5.39>1.729), it means that there is a significant difference between the students' speaking ability in accuracy before and after using debate. The table also shows that t-test value for fluency is greater than t-table $(7.35>1.729)$, it is improved; it means that there is a significant difference between the students' speaking ability in fluency before and after using debate technique. it is said that the null hypothesis $\left(\mathrm{H}_{0}\right)$ is rejected and the alternative hypothesis $\left(\mathrm{H}_{1}\right)$ is accepted. It means that there is a significant difference between the students' speaking ability before and after using debate technique in speaking process, or it can be said that the use of debate technique effective in improving the students' speaking ability at the eleventh grade in SMA Perguruan Islam Makassar)

\section{B. Discussion}

Based on the presentation of findings, the researcher presents some interpretation of findings in order to explain them in details as follow:

This speaking test used two components of writing namely: accuracy, and fluency. The description of the data collected through speaking test was explained in the previous section showed that the students' ability in speaking improved. The using of debate technique was effective in improving the students' speaking ability of accuracy, and fluency.

It was supported by the mean score of students on pre-test in accuracy was 4.83 which were categorized as poor and the mean score of the students on the post test was 6.85 were categorized as fairly good. The mean score on pre-test in fluency was 5.1 which were categorized as poor classification and the mean score of the students on the post-test was 7.5 which were categorized as fairly. It means 
that the using of debate technique effective in improving the students' speaking ability in fluency.

The description of the data collected using speaking test which has explained in the previous section showed that the student's ability in speaking was developed. it supported by the students' scores in pretest and post test from the indicators. The student's score of accuracy 96.6 in pretest is different from post test 137.1,it means that has developed between before and after giving treatment. The student's score of fluency98.4 in pre-test is different from post test 150 .it means that has developed between before and after giving treatment. The students' mean score in pre-test and post -test of indicator. The students' mean score of accuracy 4.84 is classified as poor; in fluency is 5.1 which is classified as poor in pre-test. And the mean score of the students' accuracy in post test become 6.85 which is classified as good, in fluency become 7.5 which classified as good.

The results of t-test also supported this improvement. The final result from accuracyand fluency shows that t-test value for the final score of students' speaking ability6.35.>t-table $=1.729$, it is said that the null hypothesis $\left(\mathrm{H}_{0}\right)$ is rejected and the alternative hypothesis $\left(\mathrm{H}_{1}\right)$ is accepted. It means that there is a significant difference between the students' speaking ability before and after using debate technique in speaking process, it is improved or also can said that the use of debate technique effective in improving the students' speaking ability at the SMA Perguruan Islam Makassar)

\section{CONCLUSION}

Based on discussion proposed in previous chapter, the researcher concludes that using debate technique improves the students' speaking ability in accuracy and fluency at the second year students' speaking ability in SMA perguruan islam Makassar. It is proved by the mean score of students on pre-test in accuracy was 4,83 . This was categorized as poor category and after post-test was 6.85 become fairly. The mean score on pre-test in fluency was 5.1. This was categorized as poor and after post-test were 7.5 becomes good. 


\section{BIBLIOGRAPHY}

Arikunto, S. 2001. Dasar-Dasar Evaluasi Pendidikan. Jakarta: Bumi Aksara

Azma. 2008. Improving Students' Speaking Skill Through Debate At Grade X II IS 2 Of SMA Negeri I Pasaman. Thesis. Padang unpublished.

Barkley, Robert and meany, john rhetoric and director of debate bates college and director of forensics Claremont mc kenna college 1998. Parliamentary Debate. //httpdebate.uvm.edumeanyparli.html. retrieved January 12, 2005 at 193 .

Brown, G and Yule, G. 1994. Teaching Spoken Language: An Approach Based On The Analysis Of Conversational English. Cambridge: Cambridge university press.

Clark, H and Eve Clark 1977. Psychology And Language: An Introduction To Psycholinguistic. New York Harcourt brace Jovanovich

Dobson, M Julia. 1987. Effective Techniques For English Conversation Groups. Washington

Finochioaro, Mary. 1983. Foreign Language Testing; A practical Approach. New York: Regent Publishing Company.

Gay, L. J. 1987. Educational Research: Competences Analysis and Application. Columbus: Merill Publishing Company

Halvorsen andy 2005. Incorporating Critical Thinking Skills Development Into ESL/EFL Course. http://iteslj.org/Techniques/HalvorsenCriticalThinking.html Retrieved January 24, 2009 at 10:46

Hanar. 2007. Developing Students' Speaking Performance Through Cooperative Learning. Thesis FKIP Universitas Muhammadiyah.

Harmer, Jeremy 1990 The Practice Of English Language Teaching. New York: Longman inc.

Harris, D.P 1994. Testing English as a Second Language. New York . Mc.Grow hill. Hill

Hornby, 1990. Teaching English to Speakers of Other Language. London: Cambridge University Press.P:1227

Inoue, N. 1996. Tradition Of Debate In Japan http://www.rc.kyushuu.ac.jp/\%7Einouen/deb-trad.html retrieved Augustus 16, 2008 at 20:23 
Kanyi, hayriye 2006. Teaching Speaking Activities To Promote Speaking In A Second Language. http://iteslj.org/Articles/Kayi-Teaching Speaking.html Retrieved January 24, 2009 at 10:46

Khoironiyah. 2011. The Implementation Of Debate In Teaching Speaking At Eleventh Year Students Of SMA Negeri 2 Rembang. FKIP UNIROW Tuban.

Kidd, A. (2002). The oxford union rough guide to debating. The English Speaking Union. Retrieved August 26, 2002 from the World Wide Web:http://www.britishdebate.com/resources/hb_oxfordguide.htm.

Krieger, Daniel 2007. Teaching Debate To ESL Students : A Six-Class Unit. http://iteslj . org/Techniques/Krieger-Debate.html Retrieved January 24, 2009 at $10: 46$

Lawtie, Fiona 2007. Teaching Speaking Skill: 2- Overcoming Classroom Problem. http://www.teachingenglish.org.uk/think/speak.html Retrieved January 24, 2009 at 10:46

Mead, Nancy A and Donal L Rubbin. 1995. Assessing Listening And Speaking Skill. ERIC DIGEST. hhtp://www.ericdigests.org/pre-923/speaking.htm. retrieved September 12, 2008.

Mowbray and George 1992. Modul 7: The Art Of Debating. http://www.gaskedgov.sk.ca/does/comma20/mod7.html retrieved January 24,2009 at $10: 46$

Mukminatien, H. G. 1999. Teaching Language as Communication. New York: Oxford University Press

Nunan, David 2003. Practical English Language Teaching. New York : Mc Graw O’Malley, Michael. 1996. Developing Second Language Skill: Theory To Practice, Third Edition. Chicago. Rand McNally College Publishing.

P. Vargo, Steven. 2012. Teaching Debate. United States Military Academy:West Point

Renkema, Wilga. 1993. Teaching Foreign Language Skill. New York: The University of Chicago. 
Riskandi. 2007. Improving Student Speaking Skill And Motivation Through English Debate Activities At SMK NEGERI 1 Bangko. Unpublished Thesis.

Rosyidah, Nashihatur. 2013. The Effectiveness Of Debate In Improving Students' Speaking Ability At Twelfth Grade Student Of Sman 3 Ponorogo In Academic Year 2012/2013. State Islamic College Of Ponorogo.

Shumin, Kang. 1997 Factor To Consider : Developing Adult Efl Students' $\begin{array}{llll}\text { Speaking } & \text { Abilities. } & \text { (July-September }\end{array}$ http://exchanges.state.gov/forum/vols /vol35/no3/p8.htm. retrieved September 12, 2008 at 20:05

Siti, Ni'amah.2012. Teaching Speaking Using Debate Activity To The Third Year Students Of Junior High School At Mambaus Sholihin Boarding School.Thesis.Unismuh Makassar.

Stewart, T AND Pleisch, G 1998 Developing Academic Language Skill And Fluency Through Debate. http://www.language. hyper. chubu. ac. jp/jalt/pub/tlt/98/okt/ steward. html. retrieved September, 152008 at 20:05 Sudjana. 1989. Metode Statistika. Bandung: Tarsito

Thirumalai, M.S 2002. An Introduction To TESOL: Teaching English To Speakers Of Other Language. Language in indie. http://www.language in india.com/april2002/tesol book.html\#chapter5 retrieved October 20, 2008 at 20:05. 